\title{
Pakistan-Afghanistan Border: The Last Hurdle for Polio Eradication
}

\author{
Umair Hamid $^{1 *}$, Faryal Ali ${ }^{2}$ and Uzair Hamid ${ }^{3}$ \\ ${ }^{1}$ Department of Pharmacology, The University of Lahore, Pakistan \\ ${ }^{2}$ Internal Medicine, Dow University of Health Sciences, Karachi, Pakistan \\ ${ }^{3}$ Internal Medicine, Allama Iqbal Medical College, Pakistan
}

Submission: November 20, 2018; Published: January 09, 2019

*Corresponding author: Umair Hamid, Department of Pharmacology, The University of Lahore, Internal Medicine, Indus Hospital, Pakistan

\section{Abstract}

The polio eradication campaign in Pakistan has seen a great number of setbacks in the last ten years. Pakistan and its neighboring country Afghanistan are the only two remaining countries that still harbor wild polio virus cases. Most of the obstacles in the path towards making these two nations polio-free have been tackled over the years, yet one major hurdle remains to be an unwavering setback for these campaigns. The border between Pakistan and Afghanistan has always been porous and unchecked migration still takes place between both these countries. This issue has been a prevalent setback through the polio vaccination history. The majority of cases that have been found are saturated in the region that lies along the border. Despite the relentless efforts by thousands of social workers and administrations of both countries, the border violations have led to a redistribution of the polio virus.

\section{Introduction \& Background}

The Global Polio Eradication Initiative partnership was launched in 1988 which has 4 components i.e. routine infant immunization, Supplementary Immunization Activities (SIAs) in at-risk middle- and low-income countries, surveillance for Acute Flaccid Paralysis (AFP), and mop-up campaigns [1,2]. SIAs (also known as National Immunization Days and Sub-National Immunization Days) deliver OPV via periodic, highly organized campaigns conducted door-to-door or at fixed sites within population centers [2]. Typically, a campaign lasts a few days and targets all children within a specific age range (usually under 5 years) without taking into consideration prior OPV immunization history [2].

In Pakistan, as of February 2018, nearly 260,000 vaccinators and 2,100 social mobilizers have worked tirelessly to vaccinate around 39 million children with a vaccination acceptance of 95\%, thus resulting in a 97\% reduction in polio cases since 2014 [1].

\section{Mini Review}

The polio eradication campaign in Pakistan has faced quite a few challenges in the last decade, most of which became obstacles in the journey towards the campaign's completion and success. A few of the core resistance have been in the shape of interference of militant groups in the northern tribal areas, religious misinterpretation and misconceptions about polio vaccine, natural calamities, lack of awareness, socio-political factors, inadequate resources and most importantly, killings of polio vaccinators by various extremist groups. Tehreek-e-Taliban Pakistan (TTP), a militant group, has remained a viable threat to polio workers and till date, it has targeted many workers and security keepers in the areas of KPK and FATA (Federally Administered Tribal Areas).

Before 2014, a great number of polio campaigns had to be halted because of an imminent or a probable terrorist attack Due to a military operation titled Zarb-e-Azb launched by the Pakistan Army, around 200,000 children were left unvaccinated in the areas of North Waziristan in the province of Khyber Pakhtun Khwa (KPK) [3]. After the success of this operation, the cases within KPK have dropped considerably from 68 cases reported in 2014 to 1 case in 2017.

In 2007, a qualitative assessment identified the underlying cause of refusal to OPV. It was highlighted that most individuals wrongfully believed that OPV vaccine contained birth control or pork (prohibited in Islam) which is clearly against Islamic beliefs [4]. A study conducted in 2011 in the districts of Swat, a polio endemic region of Northern Pakistan, stated that OPV refusal range was from $0-33 \%$. Among these districts, mothers unwilling to allow OPV for their children ranged from $0.5-5.7 \%$. The inhabitants of these districts had similar aforementioned reasons for rejecting or avoiding vaccinations [5].

With the local Islamic clerics and their staunch stance on the necessity of polio vaccination coming to the forefront, the misconception regarding vaccine and vaccine refusal has been overcome considerably. These religious scholars also issued a Fatwa (Islamic decree) in favor of polio vaccine, calling it Halal (permissible in Islam) [6]. They also clarified that there are no 


\section{Open Access Journal of Neurology \& Neurosurgery}

religious or health-related issues with these vaccines. Apart from these efforts, a laboratory controlled by the Drug Regulatory Authority of Pakistan has also tested polio vaccine and declared it Halal [7].

Another major obstacle in polio eradication has been the lack of awareness and the lack of resources. A study conducted in 2010 by UNICEF in the city of Peshawar, the capital of the KPK province, surprisingly showed that $23.3 \%$ of people were not even aware of polio vaccine and a further $21 \%$ complained that immunization centers were quite distant from their locality [8]. However, these problems are being tackled by increasing the resources as well as Table 1: Polio Cases Province Wise.

\begin{tabular}{|c|c|c|c|c|c|}
\hline Province & Cases in 2014 & Cases in 2015 & Cases in 2016 & Cases in 2017 & Cases in 2018 \\
\hline Punjab & 4 & 2 & - & 1 & - \\
\hline Sindh & 30 & 12 & 8 & 2 & - \\
\hline Kyber Pakhtunkhwa & 68 & 17 & 8 & 1 & - \\
\hline Balochistan & 25 & 7 & 2 & 3 & 3 \\
\hline FATA & 179 & 16 & 2 & - & - \\
\hline Gilgit Baltistan & - & - & - & 1 & - \\
\hline Azad Jammu Kashmir & - & - & - & - & - \\
\hline Pakistan & 306 & 54 & 20 & 8 & 3 \\
\hline
\end{tabular}

The majority of cases reported in both countries in the last year have are strangely correlated to the Pakistan-Afghanistan border. When plotted on the map, these cases lie along, on or near the border. As of July 31, 2018, only three cases have been reported in Pakistan. All three of these have been pinpointed in the Dukki district of Baluchistan, the southern Pakistani province that borders Afghanistan [1]. In 2015, most of the polio cases reported in Afghanistan were from the Nangarhar province which borders Pakistan. An evidence of genetic link of Nangarhar cases to cases in Pakistan was also found [9]. India, the neighbor of Pakistan which shares an extensive border in the east once carried around $85 \%$ share of the global polio cases, that is 1,600 out of the 1,918 cases in 2002 reported worldwide were from India. However, India has not seen a single case of polio since February 2014 [10]. The situation is completely opposite in the west of Pakistan, in Afghanistan (Table 2).

Table 2: Global Wild Poliovirus Confirmed Cases Since 2013

\begin{tabular}{|c|c|c|c|c|c|}
\hline Countries & $\mathbf{2 0 1 3}$ & $\mathbf{2 0 1 4}$ & $\mathbf{2 0 1 5}$ & $\mathbf{2 0 1 6}$ & $\mathbf{2 0 1 7}$ \\
\hline Pakistan & 93 & 306 & 54 & 20 & 8 \\
\hline Afghanistan & 14 & 28 & 20 & 13 & 14 \\
\hline Nigeria & 53 & 6 & 0 & 4 & 0 \\
\hline
\end{tabular}

Data collected up till 14 $4^{\text {th }}$ August 2018 Both Afghanistan and Pakistan have been victim to political and security conflicts for many years now. Additionally, the thin border between both countries has played a huge role in virus transportation across both nations. All cases of polio in these border areas are reported in the mobile population, especially the returning displaced population [11].

The first step towards handling this problem is sealing the border, increasing surveillance in regions adjacent to the border the personnel. In Pakistan, as of February 2018, nearly 260,000 vaccinators and 2,100 social mobilizers have been working tirelessly which has resulted in a $97 \%$ reduction in polio cases since 2014 [1].

This significant reduction of wild polio cases in Pakistan in the last four years has been commendable but further initiatives are required to identify and overcome any and all remaining hurdles to achieve global polio eradication. Although polio no longer poses a threat on a global scale, it is still endemic to a few specific regions in Pakistan and Afghanistan (Table 1).

and keeping a check on the implementation of recommendations for international travelers from both countries. On December 27, 2017, Pakistan declared Polio-Free Certificate as a mandatory document for all Afghani citizens seeking a Pakistani visa [12]. In 2017, 19 WHO-supported vaccination posts had been strategically positioned along the border with the sole purpose of vaccinating children crossing between countries [13]. During the year 2017, over 44,000 children (under the age of 10) that crossed in to Afghanistan from Pakistan and Iran had been vaccinated [13-15].

The determination of social workers and vaccinators working door-to-door and on the border have made a huge difference in the region. Bill and Melinda Gates Foundation, a major supporter of GPEI, is also working with the Government of Pakistan and WHO to enhance polio surveillance and outbreak responses. National Emergency Plans have been implemented and the quality of vaccinations have been improved in an effort to globally eradicate polio. In the long run, bilateral cooperation and vigorous efforts from both countries will is the key towards eradication and, eventually, elimination of polio from our pale blue dot in the universe.

The South-East Asia has faced multiple hindrances towards becoming polio-free. Many of these hurdles have been removed whereas efforts are in place to remove the remaining few. The remaining main obstacle is the leaky Pakistan-Afghanistan border that has been causing redistribution of the virus on both sides of the Durand line. This has led to incidence of wild polio cases within the region. Once this issue is resolved in its entirety, the eradication of the virus from this endemic region will be a definite possibility, further resulting in the global eradication and elimination of the polio virus.

\section{Conclusion}




\section{References}

1. http://www.endpolio.com.pk/media-room/pakistan-polio-update.

2. Wright PF, Kim-Farley RJ, de Quadros CA, Robertson SE, Scott RM, et al. (1991) Strategies for the global eradication of poliomyelitis by the year 2000. N Eng J Med 325(25):1774-1779.

3. Ashfaq Yusufzai (2017) Military operations pave way for vaccination in FATA, KP.

4. Murakami H, Kobayashi M, Hachiya M, Khan ZS, Hassan SQ et al (2014) Refusal of oral polio vaccine in northwestern Pakistan: a qualitative and quantitative study. Vaccine. 32(12):1382-1387.

5. Naeem M, Adil M, Abbas SH, Khan MZ, Naz SM, et al. (2011) Coverage and causes of missed oral polio vaccine in urban and rural areas of Peshawar. J Ayub Med Coll Abbottabad 23(4): 98-102.

6. Fatima Riaz, Yasir W (2014) Polio eradication challenges in Pakistan The Lancet Infectious Diseases. 14(9):791-792.

7. https://www.dawn.com/news/1156931

This work is licensed under Creative Commons Attribution 4.0 Licens

DOI: 10.19080/OAJNN.2019.09.555767
8. RB Aylward (2006) Eradicating polio today's challenges and tomorrow's legacy. Ann Trop Med Parasitol 100(5-6): 401-413.

9. Morales M, Tangermann RH, Wassilak SG (2016) Progress toward polio eradication-worldwide, January 2016-March 2018. Morbidity and mortality weekly report 65(18): 470-473.

10. http://polioeradication.org/polio-today/polio-now/wild-polioviruslist/.

11. http://www.endpolio.com.pk/media-room/media-releases/357-pakafghan-polio-teams-gear-up-to-work-jointly-for-polio-free-region

12. https://fp.brecorder.com/2018/01/20180101331936/.

13. http://polioeradication.org/news-post/protecting-children-frompolio-at-the-afghanistan-pakistan-border/.

14. http://www.endpolio.com.pk/polioin-pakistan/polio-cases-districtwise-2018.

15. http://polioeradication.org/polio-today/polio-now/wild-polioviruslist/.

Your next submission with Juniper Publishers will reach you the below assets

- Quality Editorial service

- Swift Peer Review

- Reprints availability

- E-prints Service

- Manuscript Podcast for convenient understanding

- Global attainment for your research

- Manuscript accessibility in different formats

( Pdf, E-pub, Full Text, Audio)

- Unceasing customer service

Track the below URL for one-step submission

https://juniperpublishers.com/online-submission.php 